Research article

\title{
The Evolution of Populism in South America: Was J. Bolsonaro's Victory in the 2018 Brazilian Presidential Election a Precedent or a Model for the Region?
}

\author{
V.G. Ivanov \\ Peoples' Friendship University of Russia (RUDN University) \\ Miklukho-Maklaya Str., 6, Moscow, Russian Federation, 117198
}

\begin{abstract}
The article analyzes the election campaign, public discourse, and policies of J. Bolsonaro as the President of Brazil. The new President represents the model of an irreconcilable right-wing populist who focuses on US foreign policy. Bolsonaro's rise to power came amid the crisis of left-wing populism in Brazil. The article raises the question: whether Bolsonaro's victory is a remarkable case or a new effective model of public policy and political leadership for Brazil and other countries in the region? The author concludes that it depends largely on J. Bolsonaro's success as the President. At the moment, the interim results of his presidency are highly controversial and continue to divide and polarize Brazilian society.
\end{abstract}

Key words: Brazil, J. Bolsonaro, President, South America, elections, populism

\section{Introduction}

General elections took place in Brazil in October 2018 to elect the President, Vice President, the highest legislative body - the National Congress, governors and state legislatures. In a surprise twist, far-right populist politician Jair Bolsonaro of the Social Liberal Party (PSL) was comfortably ahead in the election runoff and won the presidency.

Jair Bolsonaro's victory apparently marked a momentous shift not only for Brazil, but for the whole region, since results of general elections have not only secured the new President his mandate, but also enabled him to form a new alliance in the National Congress (the majority of lawmakers in the lower house of the Congress and in the Senate gave a boost to the initiatives of the new President). During the electoral campaign J. Bolsonaro created a strong platform of supporters, united by interests and values (gun lobbyists, opponents of abortion, same-sex marriage and sex education in schools, conservatives, anti-communists, right Catholics, neoliberals and agribusiness lobbyists).

(C) Ivanov V.G., 2020.

(c) (i) This work is licensed under a Creative Commons Attribution 4.0 International License https://creativecommons.org/licenses/by/4.0/ 
Thus, Bolsonaro, since taking office on January 1, 2019, relies on large propresidential social groups within the country (both systemic or situational) and enlists external support (primarily, from the administration of US President Donald Trump). Although this may not be sufficient to deliver on promises of radical constitutional changes, this is more than enough for the adoption of a number of new laws and a significant change in both domestic and foreign policy of the country [1].

The Brazilian political crisis that potentially justified harsh measures and repressions against the rivals, as well as the lingering split among his main political opponents are the factors increasing the political space for the Brazilian President. A dramatic "turn to the right" characteristic of South America in recent years began in Brazil with a massive corruption scandal that led to the impeachment of President Dilma Rousseff in 2015-16 and the imprisonment of Lula da Silva, the "people's President" who governed the country from 2003 to 2011. The winner of October 2018 elections Bolsonaro was handed over power by right-wing liberal Michel Temer, who temporarily replaced Rousseff after her removal from office.

The previous "wave of left-wing populism" of the 2000s was replaced in South American countries by the generation of ultra-liberal elitists who would not have won the elections in other conditions. Both Temer in Brazil and Macri in Argentina were classic representatives of the upper class in their countries: rich white men coming from famous business dynasties. Undoubtedly, they are estranged from the people and distance themselves from them, focusing on the highest business circles, the world economy and interests of the United States [1].

However, it is the right-wing populist leaders who can count on winning wider support of the electorate with their pre-election rhetoric. The victorious candidate went with this trend, attracting the support of a large part of the electorate in a divided Brazilian society. Here we witness a model of competition, in which the electorate is clearly segmented, and the candidate relies on loyal groups while alienating other broad layers of the population. This was the strategy behind the "toxic" rhetoric of Bolsonaro filled with sexist, racist, homophobic and antisocialist statements and comments. With the missing political center in these elections, such electoral strategies aimed at mobilizing their respective wings have proven to be very effective. Both candidates who got to the second-round runoff, Jair Bolsonaro and his opponent - the Workers' Party representative Fernando Haddad - offered diametrically opposed solutions to the multiple challenges the country is facing.

Previously, Brazilian left-wing politicians were known to "address the poor, but communicate with the rich", apparently, this is still true today, when the new President, a pronounced elitist, is also a populist, who also addresses the poorly educated and low-income population groups [1].

However, the victory of the right-populist candidate has deeper roots. Jair Bolsonaro was not just a bombastic far-right extremist and a pro-American politician with a long political career. In Brazil, Bolsonaro was usually discussed not only as an individual political figure, but also in the context of his party and his family. And if the Bolsonaro family is in the public eye and turning into the most 
influential political clan of the country - the President's three sons are successfully entrenched in politics - the party context of the Brazilian political landscape is not so widely publicized.

As is known, competitive elections have been held in Brazil since 1985, after the military dictatorship had ended. Nevertheless, according to many political analysts, in recent years (2015-2018), the economic recession and corruption scandals have sent the country into its worst crisis of governability since 1985 . This political crisis has even called into question the political model of the "Coalition Presidential System" that was once praised for its ability to manage the most fragmented party system in the world. Indeed, about 40 parties participate in Brazil's congressional elections, around 30 of which usually get different levels of representation. Therefore, the party coalitions need to be created in the National Congress of Brazil.

Moreover, all candidates obliged to have party affiliation in order to take part in the election. Many Brazilian political scientists even call the Brazilian political system "partocracy" [2;3]. Despite periods of dictatorship, political parties have steadily increased their political role in Brazil since 1945, when independent candidates were banned, and parties could only be created on a national basis. These principles, as well as the proportional electoral system of the "open list" were enshrined in the current 1988 Constitution. However, the need for the candidate's party affiliation is balanced by both a wide range of parties (Bolsonaro, for example, changed 8 parties over his 30-year political career) and the variability of their programs (for example, after Bolsonaro joined the ranks, PSL converted from social liberalism to national conservatism) [1].

In Brazil, there is much tension around the issue of parties funding, and in recent years it has become extremely politicized. The country's political system is undergoing constant changes. In the context of the 2018 general election, of particular importance is the judgement Brazil's Supreme Court delivered in 2015 banning corporations from financing electoral campaigns. This ban significantly increased the already high importance of state funding of political parties. Nevertheless, election campaigns are awash with illegal money, which also applies to PSL and leads to mutual accusations and gotcha journalism. Unabated corruption scandals involving state-owned companies and government heavyweights led to the impeachment of re-elected in 2014 President Dilma Rousseff. Her successful election campaign was discredited retrospectively, taking a heavy toll on the Workers' Party and the National Congress in general (for example, the speaker of the Chamber of Deputies was arrested).

The "55th Congress' Political Reform" that followed focused on both banning the corporate money and consolidating the party system - that is, reducing the number of parties entitled to the fund (introducing a threshold and banning electoral coalitions), which affects the allocation of public funding and increasing campaign financing by adding a new public party fund exclusively for election campaigns. However, this political reform failed to significantly reduce the number of parties, and money from corporate sponsors continues to regularly flow into 
election campaigns. The three largest parties took $35 \%$ of the public party fund, which undoubtedly makes them dependent on external funding and fuels debates about the fairness of elections [1]. Even though the information is not verified, there are compelling reasons to believe Bolsonaro managed to raise much bigger funding for his election campaign than his rivals [4].

It should also be noted that voting in Brazil is mandatory, therefore, the low turnout is not the key problem. However, the turnout rate and the numbers of blank ballots during the last two 2014 and 2018 electoral cycles turned out to be the highest.

\section{Peculiarities of Brazilian Electoral Mentality}

According to surveys, contemporary Brazil is disillusioned with the elites and at the same time has low level of confidence in the political institutions, including elections. Large-scale public opinion polls show that Brazilians are known as the most skeptical people not only in Latin America (according to Latinobarómetro Data Bank ${ }^{1}$ ), but also in the world (according to the World Values Survey project by Ronald Inglehart and Christian $\mathrm{Welzel}^{2}$ ). According to national public opinion polls, the average level of confidence in the legislature has been hovering around $30 \%$, however, in 2018 public approval of parties and the National Congress dropped to $7 \%$. The lack of confidence in the elections and support for political institutions is what focuses the electorate's attention on personalities and public assertions by the politicians rather than political party programs, creating a breeding ground for populism [5].

If former President Lula da Silva serving his sentence on controversial corruption charges were registered as a presidential candidate (which certainly sounds quite utopian), the election could have made a dramatic swing bringing about a totally different result. At the same time, the September 2018 assassination attempt on Jair Bolsonaro at a rally in Juiz de Fora boosted his ratings as well.

The backing from highly respected athletes, especially footballers, was still pivotal during the last elections [6]. Football players still become national heroes in Brazil, and the country's football honor is of paramount importance. Thus, the devastating defeat of the host nation at the 2014 FIFA World Cup 2014 plunged the country into a mass depression, which resulted in spontaneous riots and antigovernment demonstrations, contributing to a drop in Rousseff's ratings [7]. During the 2018 election campaign, the popular Brazilian footballers actively endorsed Jair Bolsonaro, which, of course, was bound to have a positive effect on his rating.

\footnotetext{
${ }^{1}$ Latinobarómetro Data Bank. Available from: http://www.latinobarometro.org/latContents.jsp. Accessed: 10.02.2019.

${ }^{2}$ World Values Survey project. Available from: http://www.worldvaluessurvey.org/wvs.jsp. Accessed: 10.02.2019.
} 


\section{Competing Candidates' Programs}

Jair Bolsonaro's main rival was Fernando Haddad - potential Lula da Silva's successor representing the Workers' Party Lula was in jail (Bolsonaro promised, if elected, to make sure he "rots in prison"3) and despite his popularity in several regions of the country, he was unable to provide game-changing assistance to his follower. Since Brazil is an extremely polarized and, according to some researchers, a split country, the candidates found themselves in the second round virtually on the opposite wings of the political spectrum.

Bolsonaro nostalgically spoke about the period of military dictatorship, named corruption and bribery as the country's core problems, advocated largescale privatization of state-owned assets, diminishing the size and bureaucracy of the federal government, toughening existing migration law, liberalization of gun ownership. He proposed to abolish "unnecessary" ministries (such as the Ministry of Economy and the Ministry of Defense) and support the free market. He advocated tax cuts for businesses through social programs, and repeatedly called for repressions against political opponents [1]. Bolsonaro's controversial approach to countering crime helped him to win a significant part of the voters. As a part of his general plan Bolsonaro vow to solve the issue of high crime rate in the country using armed forces (mentioning in his election rhetoric the possible and justified "civil war") and giving the soldiers punitive powers, lowering the age of criminal responsibility and further increasing Brazil's prison population (already 4th largest in the world). He proclaimed socialist programs involving state subsidies and dealing with high inequality issues dangerous for the country. As a result, Jair Bolsonaro acquired a reputation of Brazil's Donald Trump or "Trump of the Tropics".

The problems of the Brazilian left wing in the run-up to 2018 elections did not come down to just the impeachment of Dilma Rousseff and high-profile lockup cases. The split occurred in the left forces in the build-up to 2014 elections, and has not been effectively eliminated in 2018. Aécio Neves from the Brazilian Social Democracy Party (grandson of the first democratically elected President of Brazil after the military dictatorship ended), the main rival of ex-president Dilma Rousseff in the previous presidential election, became an important "wake-up call" for the Workers' Party. He focused on the three sensitive topics for the Brazilian society: economy, corruption, foreign policy. Neves positioned himself as an alternative who could offer something different from what the Workers' Party government had been doing for the past 12 years. He constantly criticized the government, "which in recent years has not provided economic growth, is associated with corruption and foreign policy focused only on the South". Jair Bolsonaro clearly picked this line up, and went over the top, complementing it with his right-wing populism.

\footnotetext{
${ }^{3}$ In 2019, Lula da Silva was sentenced to 13 years in prison.
} 


\section{Bolsonaro's Populism in the 2018 Elections}

Considering Bolsonaro's win, political scientists and analysts might be observing the onset of the new right-populist trend in the country. Brazil has earlier seen the wave of left-wing populism launched by President Lula da Silva. It's no coincidence that, despite their apparently opposing views, parallels have been drawn between the right-winger Jair Bolsonaro and Lula da Silva, including regarding their election campaigns and public discourse. During the elections Bolsonaro undoubtedly proved himself as a prominent right-wing populist and experienced lobbyist, a multi-term and, possibly, the brightest representative of the right-wing grouping in the Brazilian Congress, informally called "Bancada BBB" ("Bullets, Beef and Bible Caucus").

The very concept of "populism" is quite controversial and ambiguous [8]. Contemporary political science assumes there are three main components characteristic of the pre-election rhetoric of "populism":

1. National sovereignty, that is, the propensity of populists to invoke the "people" usually referred to as a homogeneous group forming unity This category also includes references to the sovereignty of the people in their national territory. Also, arguments in favor of a more direct form of government can often be observed. It should be noted that Bolsonaro reproduces these plots only in part. Yes, he speaks a lot about patriotism, God, sovereignty, and declares that he rates the "correct" dictatorship higher than "irresponsible democracy", but in his public discourse the Brazilian people are not presented as unity. He makes disparaging remarks about women, the poor and minorities, noting there are too many "superfluous" people in the country [1].

2. Anti-elitism, that is, fierce criticism of the ruling elites and political actors that underlies the populist political agenda. Authorities are usually presented as a corrupt group that betrays the nation and prevents it from displaying true sovereignty. Behind this category lies the anti-establishment rhetoric, starting with elected politicians, the media, the business elite and even the intellectual and creative elite [9]. This is particularly true of Bolsonaro, who, like other right-wing populists, rode the wave of frustration with the ruling elites, exploiting nationalist and conservative rhetoric. Obviously, if it had not been for the accumulated frustration of the population fueled by economic woes and overblown corruption scandals, Bolsonaro would have stayed in political opposition. He is an example of a crisis politician (that is, the politician coming into sight during a crisis, but not necessarily capable of effectively coping with this crisis).

3. Anti-external groups, that is, "ostracizing others". It potentially excludes the part of the population that is not considered to be "pure" and should not be allowed to "enjoy the sovereignty". The target group may vary depending on the regional and political context and is regarded as "dangerous others" or "third rate". As already noted, this component of the populist discourse is very characteristic of Bolsonaro. He is afraid of Haitian, Syrian and other migrants, calling them the "scum of humanity", declares that police should be entitled to shoot 16-year-olds 
from favelas, speaks derogatorily about sexual and ethnic minorities and does not regard semi-fictional Brazilian communists as people [10; 11].

Bolsonaro's political language can be characterized, on the one hand, as simple, reduced, colorful, emotional. On the other hand, it is dualistic and laden with references to God, the people, traditional family values, as well as intolerance, threats, accusations and insults.

\section{Bolsonaro's Win: a Precedent or a Model for Contemporary South America?}

Whether Bolsonaro's victory in the presidential race will remain a political case or a new effective model of public policy and political leadership for other countries in the region depends largely on Bolsonaro's success as the President of Brazil. At the moment, the interim results of his presidency are highly controversial and rather continue to divide and polarize Brazilian society.

In foreign policy the President is set to a complete a US sweep. This policy is driven not only by intention of Brazil's business circles, but also by his personal sympathies laying with US President Donald Trump whom he viewed as a model. Thus, Bolsonaro has indicated his intention to follow the United States' cue and relocate Brazil's embassy in Israel from Tel Aviv to Jerusalem in 2020 . He pledged to impose new tough sanctions against socialist Venezuela. Having supported H. Guaidó, Bolsonaro has already rejected the nearly century-old principle of Brazilian foreign policy, which is non-interference in the internal affairs of other countries. However, President Bolsonaro, speaking at the World Economic Forum in Davos in 2019, ruled out the possibility of military intervention in Venezuela by Brazil. The dramatic shift of Brazil towards American business is highly likely, bringing deterioration of relations with Brazil's largest trading partner, the People's Republic of China.

Nevertheless, Brazil's focus on South America will only be increasing, which makes perfect sense in the current conditions and, in general, is consistent with the vector of right-wing populist policies. Brazil will enhance the former vector, bolstering ties in South America, but relying on the United States - primarily through large-scale regional initiatives (Mercosur, UNASUR, South American Defense Council).

With Bolsonaro's implementation of his domestic policy agenda the country is even more bitterly divided. Whereas, Bolsonaro's own political positions may become quite fragile with time. The modern history of Brazil knows precedents when right-wing Presidents lost power ahead of schedule due to corruption charges (for example, Fernando Collor de Mello). As G. Kolarov wrote, "If the rightwing elite (historically, it has been comprador bourgeoisie in Latin America) could not provide bread and circuses for the masses, it would inevitably lose momentum" [7. P. 28].

The success of Jair Bolsonaro as President will depend on his ability to deliver on his promises, at least in part. 
It is highly questionable that the strategy proposed by the President to tackle violent crimes and reduce record high murder rates (over 60,000 per year) will work. Delegating crime-fighting to state governors and relieving police of responsibility can lead to more mass casualties and set the country, already known for its high rate of homicides by police, back. The President may also try to deploy the armed forces, as has already been done in the state of Rio de Janeiro, to "appease" the favelas, but this policy may be counterproductive. Finally, the main idea that Brazilians should be able to fight the criminals on their own and for this purpose have the right to buy and carry guns cannot promote the pacification of an already "heated society".

One of the most controversial Bolsonaro's statements posing a threat to society was his promise to imprison his ideological rivals, firstly, the socialists (including the former centrist President - Fernando Henrique Cardoso). There are thousands on Bolsonaro's "list of enemies". However, Brazil has an independent judiciary that can potentially block politically motivated arrests.

Brazil has been in economic recession for over 5 years in a row. Bolsonaro's political future (as well as the appeal of the political model and ideology he represents) hinges on success in the economic sphere. Therefore, his plans here are not as radical, and he will apparently try to play a second fiddle, following Brazil's financial elite [12]. The main goal of the new government is to increase the economic growth rate by all possible means. The President tackles the economic growth challenges by abolishing social programs, large-scale privatization, relaxing environmental licensing and regulation and opening the Amazon delta and tropical forests for exploitation. The latter raises serious concerns among environmentalists around the world, who fear that the Bolsonaro presidency could turn into an environmental disaster for Brazil.

\section{References}

[1] Ivanov V.G. Results of Elections in Brazil. International Anticrisis Center. 2018; 12. Available from: http://anticrisis.cc/wp-content/uploads/2018/12/Results-of-election-in-Brazil.pdf. Accessed: 10.02.2019.

[2] Nunes F., Ranülfo Melo C. Political Parties: The Case of Brazil. The Presidentialization of Political Parties Organizations, Institutions and Leaders. Ed. by G. Passarelli. UK: Palgrave Macmillan; 2015. 300 p. DOI: 10.1057/9781137482464.

[3] Varshavsky A.Y. Institutional Foundations of Intraparty Coalitions in Presidential Systems: Case of Uruguay. RUDN Journal of Political Science. 2019; 21 (4): 673-686. DOI: 10.22363/2313-1438-2019-21-4-673-686 (In Russ.).

[4] Murillo A.T., Murillo D. General Elections 2018 in Brazil: Is Democracy Restored? International Journal of Advanced Research. 2018; 6 (10): 1253-1264. DOI: 10.21474/IJAR01/7932.

[5] Gontijo C., Ramos First L. Caesarism, Populism, and the 2018 Election in Brazil. Capital \& Class. 13.11.2019. DOI: 10.1177/0309816819884670.

[6] Mundim P.S., Almeida da Silva G.M. The World Cup and Presidential Popularity in Brazil. A Journal of the Brazilian Political Science Association. 2019; 13 (3): 1-32. DOI: 19813821201900030001 . 
[7] Kolarov G. Dilma Rousseff and National Consolidation of Brazilians: Problems, Contradictions and Prospects. Political Changes in Latin America. 2015; 1 (17): 28-34 (In Russ.).

[8] Stavrakakis Y., Katsambekis G., Kioupkiolis A. et al. Populism, Anti-populism and Crisis. Contemporary Political Theory. 2018; 17 (1): 4-27. DOI: 10.1057/s41296-017-0142-y.

[9] Antonov D.E. The Use of Internet Technologies for Mobilizing the Voter Base: Features, Subjects and Prospects. RUDN Journal of Political Science. 2019; 21 (3): 538-548. DOI: 10.22363/2313-1438-2019-21-3-538-548 (In Russ.).

[10] Bacelar da Silva A.J., Robb Larkins E. The Bolsonaro Election, Antiblackness, and Changing Race Relations in Brazil. The Journal of Latin American and Caribbean Anthropology Events. 11.11.2019. DOI: 10.1111/jlca.12438.

[11] Finchelstein F. Jair Bolsonaro's Model Isn't Berlusconi. It's Goebbels. Foreign Policy. 05.10.2018. Available from: https://foreignpolicy.com/2018/10/05/bolsonaros-model-its-goebbels-fascismnazism-brazil-latin-america-populism-argentina-venezuela/. Accessed: 10.02.2019.

[12] Bruff I. The Rise of Authoritarian Neoliberalism. Rethinking Marxism. 2014; 26 (1): 113-129.

Article history:

The article was submitted on 18.04.2019.

The article was accepted on 02.02.2020.

DOI: $10.22363 / 2313-1438-2020-22-1-71-80$

Научная статья

\title{
Эволюция популизма в Южной Америке: стала ли победа Ж. Болсонару на президентских выборах в Бразилии 2018 г. прецедентом или примером для региона?
}

\author{
В.Г. Иванов \\ Российский университет дружбы народов \\ ул. Миклухо-Маклая, 6, Москва, Россия, 117198
}

\begin{abstract}
Аннотация. В статье анализируется избирательная кампания, публичный дискурс и политика Ж. Болсонару на посту президента Бразилии. Новый президент Бразилии олицетворяет собой модель непримиримого правого популиста, ориентирующегося на политику США. Приход к власти Ж. Болсонару произошел на фоне кризиса левого популизма в Бразилии. В статье ставится вопрос о том, является ли победа Болсонару примечательным кейсом или новой эффективной моделью публичной политики и политического лидерства для Бразилии и некоторых стран региона? Автор приходит к выводу, что это во многом зависит от успехов Ж. Болсонару на посту президента. В настоящий момент промежуточные результаты его президентства являются весьма противоречивыми и скорее продолжают разъединять и поляризовать бразильское общество.
\end{abstract}

Ключевые слова: Бразилия, Ж. Болсонару, президент, Южная Америка, выборы, популизм

\author{
История статьи: \\ Статья поступила в редакцию 18.04.2019. \\ Статья принята к публикации 02.02.2020.
}




\section{Информация об авторах:}

Иванов Владимир Геннадьевич - доктор политических наук, доцент кафедры сравнительной политологии Российского университета дружбы народов (ORCID ID: 0000-0002-3650-5460) (e-mail: ivanov-vg@rudn.ru).

\section{Information about the authors:}

Vladimir G. Ivanov - Doctor of Political Sciences, Associate Professor of the Department of Comparative Politics, Peoples' Friendship University of Russia (RUDN University) (Russian Federation) (ORCID ID: 0000-0002-3650-5460) (e-mail: ivanov-vg@ rudn.ru).

\section{Для цитирования:}

Ivanov V.G. The Evolution of Populism in South America: Was J. Bolsonaro's Victory in the 2018 Brazilian Presidential Election a Precedent or a Model for the Region? // Вестник Российского университета дружбы народов. Серия: Политология. 2020. Т. 22. № 1. C. 71-80. DOI: 10.22363/2313-1438-2020-22-1-71-80

\section{For citation:}

Ivanov V.G. The Evolution of Populism in South America: Was J. Bolsonaro's Victory in the 2018 Brazilian Presidential Election a Precedent or a Model for the Region? RUDN Journal of Political Science. 2020; 22 (1): 71-80. DOI: 10.22363/2313-1438-2020-22-1-71-80 